\title{
Heavy Metal Concentration in Some Common Spices Available at Local Market as well as Branded Spicy in Chittagong Metropolitan City, Bangladesh
}

\author{
PRABHANGSHU KUMER DAS ${ }^{1}$, MILTON HALDER ${ }^{1 \star}$, A.S.M. MUJIB ${ }^{1}$, \\ FARIDUL ISLAM ${ }^{1}$, ABU SAYEED MOHAMMAD MAHMUD', \\ SAMINA AKHTER ${ }^{1}$ and J.C. JOARDAR ${ }^{2}$
}

\author{
'Bangladesh Council of Scientific and Industrial Research (BCSIR), \\ Chittagong Cantonment-4220, Chittagong, Bangladesh. \\ ${ }^{2}$ Khulna University, Khulna-9208, Bangladesh.
}

http://dx.doi.org/10.12944/CWE.10.1.12

(Received: November 24, 2014; Accepted: January 20, 2015)

\begin{abstract}
A study has been conducted to evaluate some heavy metals concentration of spicy from local market of Chittagong metropolitan city, Bangladesh. Total 30 spicy samples of red chili or chili red, coriander, turmeric were collected from five different spots (Khatungonj, Chakbazar, Muradpur, Baluchora, Amanbazar) under Chittagong metropolitan city and metals as $\mathrm{Zn}, \mathrm{Cu}, \mathrm{Cr}, \mathrm{Mn}, \mathrm{Fe}$ concentration were measured. Metal concentration in red chili, coriander, turmeric were found as increasing order as $\mathrm{Cu}<\mathrm{Cr}<\mathrm{Zn}<\mathrm{Mn}<\mathrm{Fe}, \mathrm{Cu}<\mathrm{Cr}<\mathrm{Mn}<\mathrm{Zn}<\mathrm{Fe}, \mathrm{Cu}<\mathrm{Cr}<\mathrm{Mn}<\mathrm{Zn}<\mathrm{Fe}$ respectively. But the distribution of metal concentration in spicy of Chittagong metropolitan city was varied among the spots. $\mathrm{Zn}, \mathrm{Cu}, \mathrm{Cr}, \mathrm{Mn}$, Fe concentrations among the sampling spots followed the following attenuating order as Chakbazar $>$ Khatungonj $>$ Muradpur $>$ Baluchora $>$ Amanbazar, Khatungonj $>$ Chakbazar $>$ Amanbazar $>$ Muradpur $>$ Baluchora, Khatungonj $>$ Chakbazar $>$ Baluchora $>$ Amanbazar $>$ Muradpur, Khatungonj >Chakbazar $>$ Muradpur $>$ Amanbazar $>$ Baluchora, Khatungonj $>$ Chakbazar $>$ Baluchora $>$ Amanbazar >Muradpur respectively. So, spicy of Khatungonj was the highly contaminated with metal followed by chakbazar spicy and least metal concentrated spicy was in Amanbazar at Chittagong city. According to WHO (World Health Organization), $\mathrm{Cr}$ and Fe concentrations exceeded the permissible limit of heavy metals in spicy but other metal concentrations was within tolerable limit. The current research's findings will convey a strong message for the government body, policy maker to establish rules and regulation in order to protect food chain contamination, environment pollution and will be helpful for public awareness. An immediate attention from the concerned authorities is required in order to protect food chain contamination and environment pollution.
\end{abstract}

Key words: Spicy, Heavy metal, local market, Brand samples, Concentration.

\section{INTRODUCTION}

"Spice" can be identified as the dry part of a plant such as roots, leaves and seeds which give a share of food a certain flavor and pungent stimuli ${ }^{1}$. The culinary herbs and spices that are used to enhance the flavor of vegetables, soups, stir-fry, and pasta dishes can be derived from the bark, buds, flowers, leaves, fruit, seeds, rhizome, or roots of a plant. By clubbing spices and condiments into one group the International Origination For Standardization (ISO) explain that the term spice or condiment consist of natural plant or vegetable products or mixtures or thereof in whole or group form as are used for imparting flavor, aroma and piquancy to and for seasoning food ${ }^{2}$. Spices have been recognized to have some medical properties due to antioxidant and antimicrobial action ${ }^{3}$. Many spices 
have been documented to possess anti-diabetic, anti-inflammatory, and antihypertensive potential ${ }^{4}$. Natural food spices such as pepper and mustard have been reported to contain significant quantities of some trace metals ${ }^{5}$. These trace metals in spices and medicinal plants play vital role as structural and functional components of metalloprotiens and enzymes in living cells ${ }^{6}$. In the last thirty to forty years, primarily for these medicinal values, the use of spices and other herbs has increased markedly in most regions of the world including Asia, Europe and North America. But the addition of spices -that may be contaminated with trace and heavy metalsto food as a habit may result in accumulation of these metals in food chain. Subjecting to trace and heavy metals above the permissible level affect the human health and may result in illness to human fetus, abortion and preterm labor, and mental retardation to children. Adults also may experience high blood pressure, fatigue and kidney and brain troubles. Heavy metals are a element with a mass density greater than $4.5 \mathrm{~g} / \mathrm{cm}^{3}$, the essential metal like Iron, cupper, and zinc are very useful for the growth of the boy but high level are intolerable and mercury, lead, cadmium etc are toxic at very low concentration ${ }^{7}$. Heavy metal may arrive and pollute plant, vegetables, fruits and canned foods through air, water and soil during cultivation ${ }^{8}$ and also during industrial processing and packaging ${ }^{9}$. The powder of pepper (red), turmeric and coriander spices of the open local market indicated that these are processed by the individual seller. For attracting customer some businessman adds color that may contain heavy metal. These spices may be contaminated if soil contaminated with heavy metals or aerial depositions during drying on the ground or on the roof tops. Some factories may add metal into the seasonings due to wear and tear of the machinery. So, this metal is entering into our food chain through this spicy which is used for our daily life. There is no such research work in Chittagong metropolitan areas regarding to this work but event is concerning for local people due to daily news of multi media. Presence of heavy metals in spicy is need to inform to general mass people for health safety. Keeping this in mind our present study has been designed to investigate some heavy metals (as $\mathrm{Zn}, \mathrm{Cu}, \mathrm{Cr}, \mathrm{Mn}, \mathrm{Fe}$ ) concentration in local market spices as well as branded spices in Chittagong metropolitan city, Bangladesh.

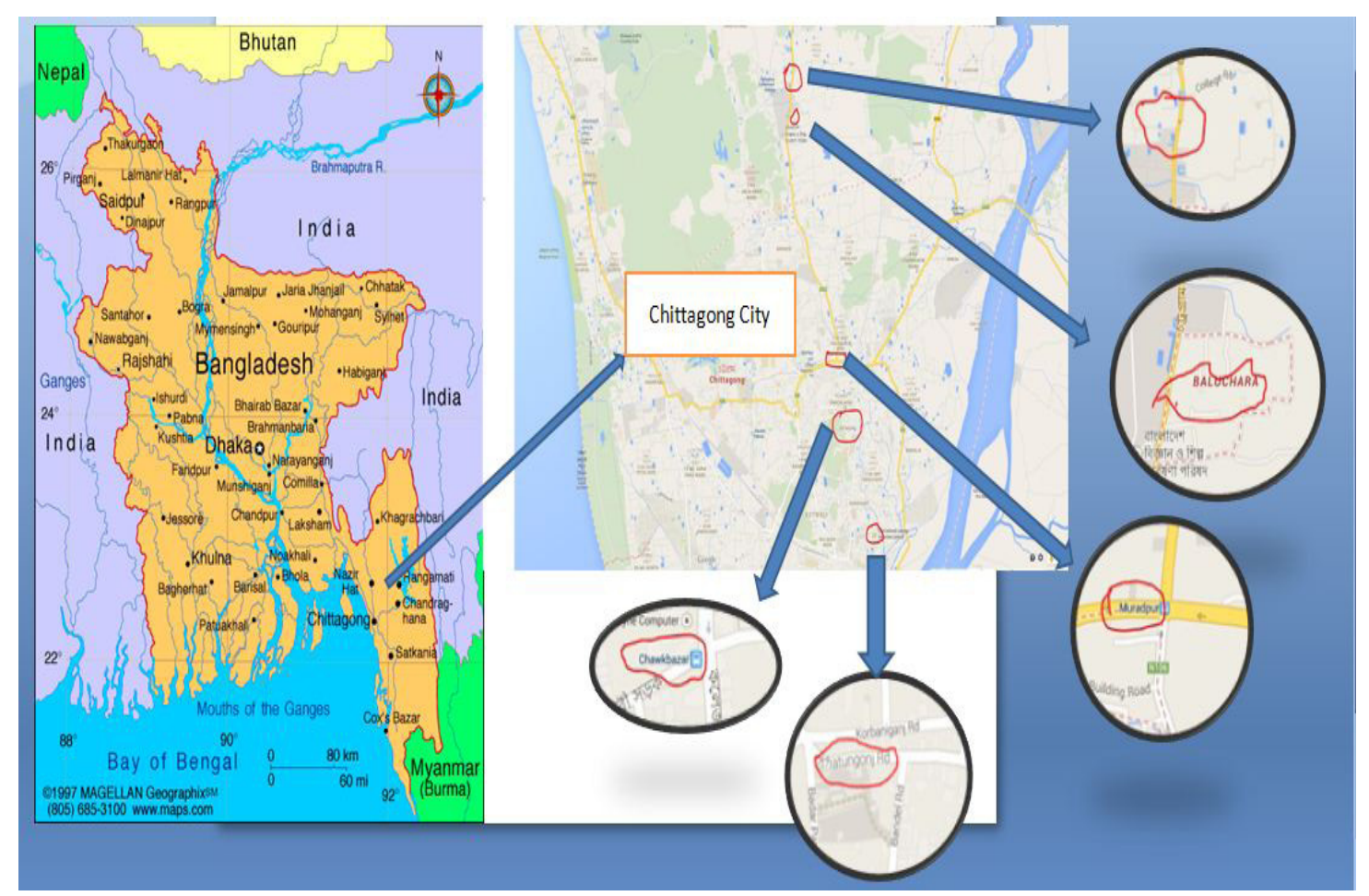

Fig. 1: The map of sampling site at Chittagong metropolitan city in Bangladesh 


\section{MATERIALS AND METHODS}

\section{Sampling area}

The sampling area was located within Chittagong metropolitan city of Bangladesh. Five sampling sites have been shown in figure 1.

Three types of powder spicy samples were collected from local market of Chittagong Metropolitan City of Bangladesh. Three types were red chili, Coriander and Turmeric. Samples were collected from five different points like as Khatungong (22 $\left.20^{\prime} 16.6^{\prime \prime} \mathrm{N} 91^{\circ} 50^{\prime} 39.4^{\prime \prime} \mathrm{E}\right)$, Chockbazar $\left(22^{\circ} 21^{\prime} 25.9^{\prime \prime} \mathrm{N} 91^{\circ} 50^{\prime} 14.1^{\prime \prime} \mathrm{E}\right)$, Muradpur (22 $\left.22^{\circ} 08.9^{\prime \prime} \mathrm{N} 91^{\circ} 49^{\prime} 59.0^{\prime \prime} \mathrm{E}\right)$, Baluchora $\left(22^{\circ} 24^{\prime} 35.0^{\prime \prime} \mathrm{N} 91^{\circ} 49^{\prime} 04.5^{\prime \prime} \mathrm{E}\right)$, Amanbazar $\left(22^{\circ} 25^{\prime} 17.6^{\prime \prime} \mathrm{N} 91^{\circ} 49^{\prime} 12.4^{\prime \prime} \mathrm{E}\right)$. Each sample was collected in five points but in two different shops and total number of each sample were ten. In this way total 30 samples were collected from different places (Table 2). After collection, all samples were leveled and stored in polythene bags and brought in laboratory for analysis. But branded samples were not need to store in polythene bag because they were already packed. Scientific name, common name, and family name of these studied spices have been given in table 1.

\section{Sample preparation and analysis}

Samples were dried in oven at $80^{\circ} \mathrm{C}$ for 8 hours, cooled, and stored in desiccators for the analysis. Initially these samples were digested by using concentrated $\mathrm{H}_{2} \mathrm{SO}_{4}$ and $30 \% \mathrm{H}_{2} \mathrm{O}_{2}$ and the concentration of the heavy metals like as $\mathrm{Cr}, \mathrm{Cu}$, $\mathrm{Zn}$, Fe and Mn were measured by using Atomic Absorption Spectrophotometer (Thermo Scientific iCE 3000 Series Atomic Absorption Spectrometer) according to the procedure of Huq and Alam, $(2005)^{10}$

Table 1: Scientific name, common name, and family name of collected spices samples from local market of Chittagong metropolitan city of Bangladesh

\begin{tabular}{lcc}
\hline $\begin{array}{l}\text { Common } \\
\text { name }\end{array}$ & Scientific name & Family \\
\hline Chili red & Capsicum annuum & Solanaceae \\
Coriander & Coriander sativum & Apiaceae \\
Turmeric & Curcuma longa & Zingiberaceae \\
\hline
\end{tabular}

\section{Statistical Analyses}

The results were expressed as the averages of ten replications. The data were subjected to ANOVA. Differences between means were statistically analyzed using Tukey's test $(p<0.05)$ performed with the SAS 6.0. Parson co efficient of correlation $(p<0.01,0.05)$ was also calculated by using SPSS 16.0. The graphs were drown in excel 2007.

\section{RESULTS AND DISCUSSIONS}

\section{Zinc concentration in spices}

In all the sample's average zinc concentration was more or less equal in range (figure 2 ). The zinc concentration was highest in turmeric as $75.5 \pm$ $22.23 \mathrm{mg} / \mathrm{kg}$ followed by red chili as $72.18 \pm 5.9 \mathrm{mg} /$ $\mathrm{kg}$ and lowest in coriander as $68.78 \pm 10.32 \mathrm{mg} / \mathrm{kg}$. The range of zinc concentration in turmeric differed from $48.97 \mathrm{mg} / \mathrm{kg}$ (at Baluchora) to $116.89 \mathrm{mg} /$ $\mathrm{kg}$ (at Chakbazar). Two branded turmeric samples retained low concentration of zinc compared to others (RADHUNI, PRAN as 50.02, $67.57 \mathrm{mg} / \mathrm{kg}$ respectively). The range of zinc concentration in chili red was found from $83.62 \mathrm{mg} / \mathrm{kg}$ (at khatungonj) to $65.48 \mathrm{mg} / \mathrm{kg}$ (PRAN brand spicy at Aman Bazar). In coriander, the range of $\mathrm{Zn}$ concentration in

Table 2: Sampling area, number of sample of collected spicy at different area of Chittagong metropolitan city of Bangladesh

\begin{tabular}{lcc}
\hline $\begin{array}{l}\text { Sample } \\
\text { collection area }\end{array}$ & $\begin{array}{c}\text { Spicy } \\
\text { name }\end{array}$ & $\begin{array}{c}\text { Sample } \\
\text { Number }\end{array}$ \\
\hline Khatungonj & Chili red & 2 \\
& Coriander & 2 \\
Turmeric & 2 \\
Chakbazar & Chili red & 2 \\
& Coriander & 2 \\
Muradpur & Turmeric & 2 \\
& Chili red & 2 \\
Balurchara & Coriander & 2 \\
& Turmeric & 2 \\
& Chili red & 2 \\
Aman Bazar & Coriander & 2 \\
(Bangladeshi Brand & Turmeric & 2 \\
as Pran and Radhuni) & Coriander & 2 \\
& Turmeric & 2 \\
\hline
\end{tabular}


determined samples was $87.89 \mathrm{mg} / \mathrm{kg}$ (at Muradpur) to $51.96 \mathrm{mg} / \mathrm{kg}$ (at Baluchora). Zinc concentration in RADHUNI and PRAN of coriander was $77.56 \mathrm{mg} / \mathrm{kg}$ and $60.78 \mathrm{mg} / \mathrm{kg}$ respectively. Zinc is an essential element for human health and in particular, zinc has been recognized as a co-factor of the superoxide dismutase enzyme, which is involved in protection against oxidative processes ${ }^{11}$. According to $\mathrm{WHO}$, permissible limits of Zinc is $100 \mathrm{mg} / \mathrm{kg}$ for spicy ${ }^{12}$. However, the concentration of zinc $(\mathrm{mg} / \mathrm{kg})$ for all the spicy was very well below the permissible limit of $\mathrm{WHO}$ and may be considered tolerable. Statistically there was no significant $(p<0.05)$ difference among the spicy in respect of $\mathrm{Zn}$ concentration.

\section{Cupper concentration in spices}

In all the sample's average cupper concentration varied in narrow range which has been shown in figure 3 . The cupper concentration was highest in coriander as $10.38 \pm 8.65 \mathrm{mg} / \mathrm{kg}$ followed by red chili as $9.23 \pm 4.45 \mathrm{mg} / \mathrm{kg}$ and lowest in turmeric as $8.3 \pm 6.53 \mathrm{mg} / \mathrm{kg}$. The range of cupper

Table 3: Pearson Correlation coefficient among the metal concentrations of red chili collected from different spot of Chittagong metropolitan city

\begin{tabular}{lccccc}
\hline & $\mathrm{Zn}$ & $\mathrm{Cu}$ & $\mathrm{Cr}$ & $\mathrm{Mn}$ & $\mathrm{Fe}$ \\
\hline $\mathrm{Zn}$ & 1 & .402 & .441 & .479 & .484 \\
$\mathrm{Cu}$ & & 1 & $.747^{*}$ & $.894^{* *}$ & .096 \\
$\mathrm{Cr}$ & & & 1 & $.689^{*}$ & -.268 \\
$\mathrm{Mn}$ & & & & 1 & .306 \\
$\mathrm{Fe}$ & & & & & 1 \\
\hline
\end{tabular}

*. Correlation is significant at the 0.05 level.

**. Correlation is significant at the 0.01 level.

Table 4: Pearson correlation coefficient among the metal concentration of coriander collected from different spot of Chittagong metropolitan city

\begin{tabular}{lccccc}
\hline & Zn & Cu & Cr & Mn & Fe \\
\hline $\mathrm{Zn}$ & 1 & .407 & -.033 & .300 & .279 \\
$\mathrm{Cu}$ & & 1 & $.752^{*}$ & .087 & .511 \\
$\mathrm{Cr}$ & & & 1 & .263 & .551 \\
$\mathrm{Mn}$ & & & & 1 & .417 \\
$\mathrm{Fe}$ & & & & & 1 \\
\hline
\end{tabular}

concentration in coriander differed within a wide range from $0.56 \mathrm{mg} / \mathrm{kg}$ (at Baluchora) to $24.90 \mathrm{mg} /$ $\mathrm{kg}$ (at khatungonj). Two branded spicy of coriander contained low concentration of cupper compared to others (RADHUNI, PRAN as $7.27,3.42 \mathrm{mg} / \mathrm{kg}$ ). The range of cupper concentration in chili red was found from $4.35 \mathrm{mg} / \mathrm{kg}$ (at Muradpur) to $17.25 \mathrm{mg} /$ $\mathrm{kg}$ (at khatungonj). For turmeric, range of cupper concentration in determined samples was $1.01 \mathrm{mg} /$ $\mathrm{kg}$ (RADHUNI brand at Aman bazar) to $17.29 \mathrm{mg} /$ $\mathrm{kg}$ of sample collected from Muradpur. According to $\mathrm{WHO}$, permissible limits of cupper is $50 \mathrm{mg} / \mathrm{kg}$ for spicy ${ }^{12}$. Cu concentration $(\mathrm{mg} / \mathrm{kg})$ in all the spicy samples was below the WHO recommended level. Therefore, limit of $\mathrm{Cu}$ are very tolerable for all the samples collected from Chittagong metropolitan city. Statistically, there was no significant $(p<0.05)$ difference among the spicy in respect of $\mathrm{Cu}$ concentration.

\section{Chromium concentration in spices}

$\mathrm{Cr}$ concentration for all the spicy differed within a very narrow range shown in figure 4 . The $\mathrm{Cr}$ concentration of spicy as coriander, turmeric, chili red was measured as $41.83 \pm 9.6 \mathrm{mg} / \mathrm{kg}, 39.74 \pm$ $8.40 \mathrm{mg} / \mathrm{kg}, 39.43 \pm 8.68 \mathrm{mg} / \mathrm{kg}$ respectively. The concentration of $\mathrm{Cr}$ in coriander was found highest in Khatungonj as $55.68 \mathrm{mg} / \mathrm{kg}$ and lowest in brand sample PRAN (31.11 mg/kg) at Amanbazar. In turmeric, $\mathrm{Cr}$ concentration varied from $30.96 \mathrm{mg} /$ $\mathrm{kg}$ in Muradpur to $53.58 \mathrm{mg} / \mathrm{kg}$ in Chackbazar. For PRAN and RADHUNI brand, $\mathrm{Cr}$ concentration in turmeric was measured as $38.24 \mathrm{mg} / \mathrm{kg}, 39.74 \mathrm{mg} /$ $\mathrm{kg}$ respectively. But $\mathrm{Cr}$ concentration in chili red obtained from 27.43 to $55.29 \mathrm{mg} / \mathrm{kg}$ at Muradpur,

Table 5: Pearson correlation coefficient among the metal concentrations of turmeric collected from different spot of Chittagong metropolitan city

\begin{tabular}{lccccc}
\hline & Zn & Cu & Cr & Mn & Fe \\
\hline $\mathrm{Zn}$ & 1 & $.687^{*}$ & .483 & $-.793^{\star \star}$ & .436 \\
$\mathrm{Cu}$ & & 1 & $.867^{\star \star}$ & $-.871^{\star \star}$ & .501 \\
$\mathrm{Cr}$ & & 1 & $-.779^{* \star}$ & .366 \\
$\mathrm{Mn}$ & & & 1 & -.556 \\
$\mathrm{Fe}$ & & & & 1 \\
\hline *. Correlation is significant at the 0.05 level. \\
**. Correlation is significant at the 0.01 level.
\end{tabular}


Khatungonj respectively. However, the permissible limit of $\mathrm{Cr}$ recommended by WHO is $30 \mathrm{mg} / \mathrm{kg}^{12}$. Average $\mathrm{Cr}$ concentration $(\mathrm{mg} / \mathrm{kg})$ in all the spicy was higher than WHO recommended value. So, it is very concerning for $\mathrm{Cr}$ toxicity. $\mathrm{Cr}$ has numerous effects due to toxicity like as Kidney disease, Liver disease, Diabetes, Chromate/leather contact allergy, Behavioral or psychiatric conditions such as depression, anxiety, or schizophrenia. Chromium particularly $\mathrm{Cr}$ (III) plays an important role in the body function in trace amount but it is toxic in excess amount. The high concentrations of $\mathrm{Cr}$ was found in these spicy items may be explained by several factors such as the metal content of the soil, variation

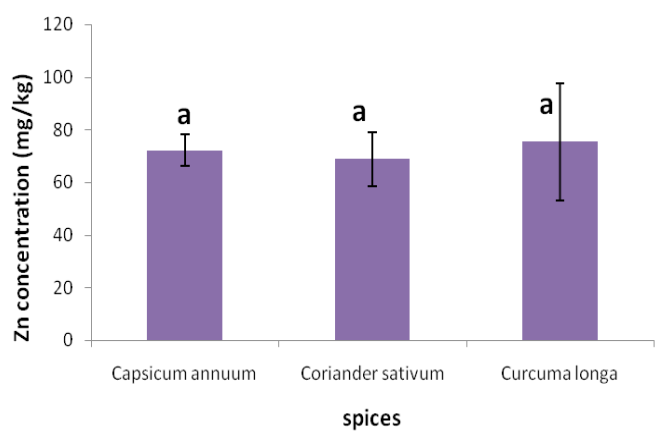

Fig. 2: Average zinc concentration ( $\mathrm{mg} / \mathrm{kg}$ ) of three spicy collected from different places of Chittagong metropolitan city, Bangladesh. Means followed by the same letter are not significantly different $(P<0.05)$. Error bars represent the standard deviations (SDs), $(n=10)$.

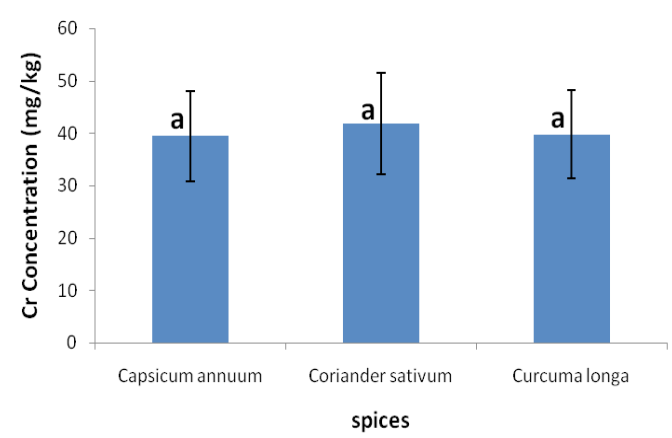

Fig. 4: The concentration of $\mathrm{Cr}$ in three spicy in different place of Chittagong metropoliton city of Bangladesh. Means followed by the same letter are not significantly different $(P<0.05)$. Error bars represent the standard deviations (SDs), $(n=10)$. in element uptake by different plants, and fertilization and processing techniques ${ }^{8,9}$. Statistically, there was no significant $(p<0.05)$ difference among the spicy in regarding to $\mathrm{Cr}$ concentration.

\section{Manganese concentration in spices}

Mn concentration in selected three spicy at different places of Chittagong metropolitan city areas was determined and showed wide range of variation (Figure 5). The highest concentration of $\mathrm{Mn}$ was found in turmeric as $76 \pm 34.1 \mathrm{mg} / \mathrm{kg}$ followed by chili red $74.02 \pm 42.6 \mathrm{mg} / \mathrm{kg}$ and least in coriander as $52.91 \pm 24.62 \mathrm{mg} / \mathrm{kg}$. Among the collected samples of turmeric, highest concentration of $\mathrm{Mn}$ was found

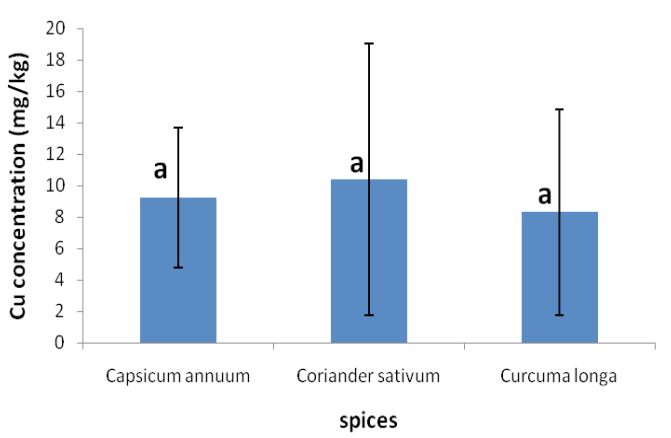

Fig. 3: Cupper concentration of three spicy collected from different places of Chittagong metropolitan city, Bangladesh. Means followed by the same letter are not significantly different $(P<0.05)$. Error bars represent the standard deviations (SDs), $(n=10)$.

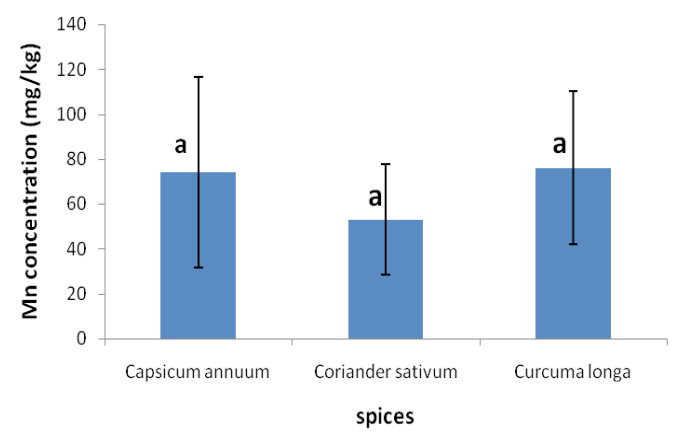

Fig. 5: Mn concentration in selected three spicy collected from different areas of Chittagong metropolitan city of Bangladesh. Means followed by the same letter are not significantly different $(P<0.05)$. Error bars represent the standard deviations (SDs), $(n=10)$. 
in brand sample of RADHUNI at Amanbazar (113.05 $\mathrm{mg} / \mathrm{kg}$ ) and least in Muradpur as $34.84 \mathrm{mg} / \mathrm{kg}$. In case of chili red, range of Mn concentration differed within a wide range from $30.46 \mathrm{mg} / \mathrm{kg}$ (Brand sample of PRAN at Aman bazaar) to $132.7 \mathrm{mg} / \mathrm{kg}$ (Muradpur). Finally, the concentration of $\mathrm{Mn}$ in coriander was observed from $31.39 \mathrm{mg} / \mathrm{kg}$ in RADHUNI brand at Amanbazar to $104.73 \mathrm{mg} / \mathrm{kg}$ at Baluchora local market's sample. The WHO recommended limit for $\mathrm{Mn}$ is $100 \mathrm{mg} / \mathrm{kg}$ [12]. Mn concentration in most of the spicy was below the WHO recommended limit. It was very well below the limit and can be considered tolerable. But in RADHUNI brand and Baluchara local market spicy samples contained unusual concentration of $\mathrm{Mn}$ which exceed the WHO

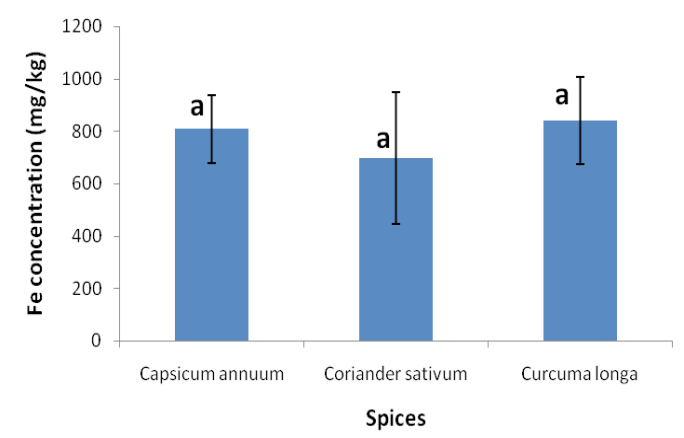

Fig. 6: Iron concentration in selected three spicy samples collected from Chittagong Metropoliton city of Bangladesh. Means followed by the same letter are not significantly different $(P<0.05)$. Error bars represent the standard deviations (SDs), $(n=10)$.

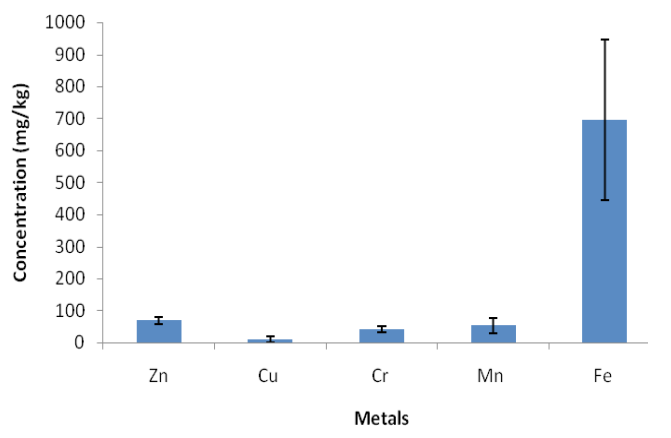

Fig. 8: Average metal ( $\mathrm{Zn}, \mathrm{Cu}, \mathrm{Cr}, \mathrm{Mn}$, and $\mathrm{Fe})$ concentrations in Coriander collected from different spot of Chittagong metropolitan city of Bangladesh. Error bars represent the standard deviations (SDs), $(n=10)$. recommended limit. Mn concentration at these two places need to continuous monitoring and need further study to conform it. Statistically, there was no significant $(p<0.05)$ difference among the spicy regarding to $\mathrm{Mn}$ concentration.

\section{Iron concentration in spices}

The average iron concentration in all the sample differed widely shown in figure 6 . The iron concentration was highest in turmeric as $840.69 \pm$ $165.52 \mathrm{mg} / \mathrm{kg}$ followed by red chili as $807.60 \pm 128.89$ $\mathrm{mg} / \mathrm{kg}$ and lowest in coriander as $695.91 \pm 251.72$ $\mathrm{mg} / \mathrm{kg}$. The range of iron concentration in turmeric varied from $605.83 \mathrm{mg} / \mathrm{kg}$ (at Muradpur) to 1124.97 $\mathrm{mg} / \mathrm{kg}$ (at Baluchorr). Two branded spicy of turmeric

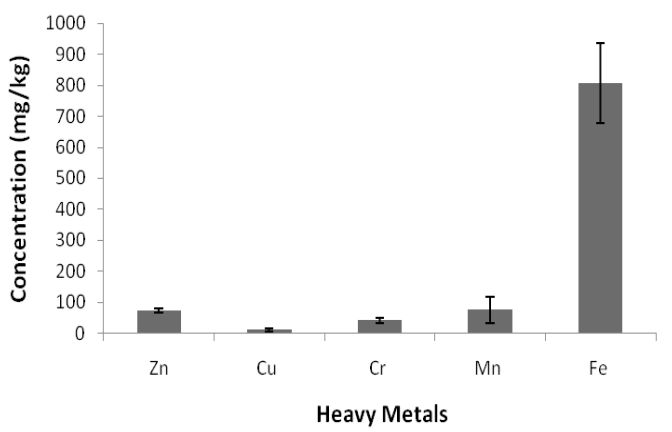

Fig. 7: Average metal ( $\mathrm{Zn}, \mathrm{Cu}, \mathrm{Cr}$, Mn, and $\mathrm{Fe}$ ) concentrations in Coriander collected from different local market of Chittagong metropolitan city of Bangladesh. Error bars represent the standard deviations (SDs), $(n=10)$.

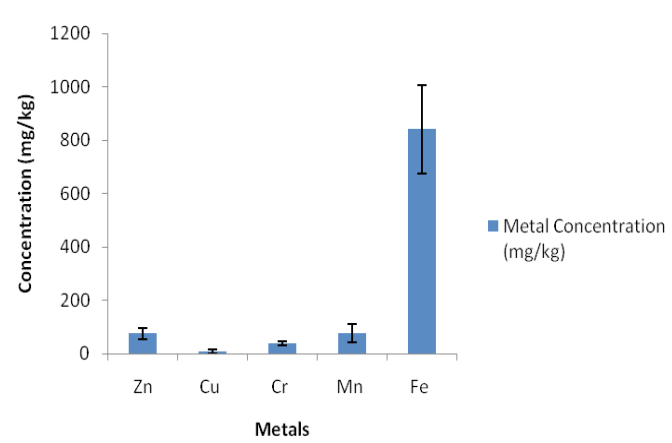

Fig. 9: Average metal ( $\mathrm{Zn}, \mathrm{Cu}, \mathrm{Cr}, \mathrm{Mn}$, and Fe) concentrations in Turmeric collected from different places of Chittagong metropolitan city of Bangladesh. Error bars represent the standard deviations (SDs). $(n=10)$ 
retained low concentration of iron compared to others (RADHUNI, PRAN as 851.38, $740.17 \mathrm{mg} /$ $\mathrm{kg})$. The range of iron concentration in chili red was found from $559.96 \mathrm{mg} / \mathrm{kg}$ (at khatungonj) to 965.43 $\mathrm{mg} / \mathrm{kg}$ (at Baluchora). In coriander, the range of iron concentration in determined samples varied widely from $100.28 \mathrm{mg} / \mathrm{kg}$ (at Muradpur) to $926.9 \mathrm{mg} / \mathrm{kg}$ (at Chackbazar). Iron concentration of coriander in RADHUNI and PRAN was $660.38 \mathrm{mg} / \mathrm{kg}$ and $475.28 \mathrm{mg} / \mathrm{kg}$ respectively. Iron is also an essential element and a common element in humans and plants. They occur predominantly in plants in the form of phytate complexes. They may also be in the form of inorganic iron salts such as Ferric hydroxides. However, the permissible limit of $\mathrm{Fe}$ is $300 \mathrm{mg} / \mathrm{Kg}$ recommended by $\mathrm{WHO}^{12}$. Average Fe concentration $(\mathrm{mg} / \mathrm{kg})$ in all the spicy in collected from Chittagong metropolitan city of Bangladesh contained high level of $\mathrm{Fe}$ and cross the limit of WHO recommended. So, this research report is very much concerning regarding to iron concentration in spicy of Chittagong metropolitan city of Bangladesh. Statistically, there was no significant $(p<0.05)$ difference among the spicy for Fe concentration.

\section{Comparison among the metals concentrations $(\mathrm{mg} / \mathrm{kg})$ in Chilli red}

Heavy metal Concentrations in chili red was differed with in a wide range (figure 7). The order of these metal concentration was $\mathrm{Cu}<\mathrm{Cr}<\mathrm{Zn}<\mathrm{Mn}<\mathrm{Fe}$ in red chili spicy. Statistically, $\mathrm{Cu}\left(r=0.894^{* *}, p<0.01\right)$ and $\mathrm{Cr}\left(\mathrm{r}=0.689^{*}, \mathrm{p}<0.05\right)$ concentration significantly correlated with $\mathrm{Mn}$ concentration in red chili. Concentration of $\mathrm{Cr}$ also significantly $\left(r=0.747^{*}\right.$, $\mathrm{p}<0.05)$ correlated with Cu concentration in red chili. turmeric collected from different spot of Chittagong metropolitan city has been given in table 3, 4, 5 respectively.

\section{Comparison among the metals concentrations $(\mathrm{mg} / \mathrm{kg})$ in coriander}

Fe concentration was the highest among the measured metal concentration (Figure 8). The order of these metal concentration was $\mathrm{Cu}<\mathrm{Cr}<\mathrm{Mn}<\mathrm{Zn}<\mathrm{Fe}$ in coriander spicy. Statistically, $\mathrm{Cr}$ concentration significantly $\left(r=0.752^{*}, p<0.05\right)$ correlated with $\mathrm{cu}$ concentration in coriander.

\section{Comparison among the metals concentration $(\mathrm{mg} / \mathrm{kg})$ in Turmeric}

$\mathrm{Cu}$ concentration was found lowest in not only turmeric but also in other the spicy like as red chili, coriander (figure 9). The metals order in turmeric spicy was $\mathrm{Cu}<\mathrm{Cr}<\mathrm{Mn}<\mathrm{Zn}<\mathrm{Fe}$. Statistically, $\mathrm{Zn}$ concentration significantly correlated with $\mathrm{Cu}$ $\left(r=0.687^{*}, p<0.05\right)$ and $\mathrm{Mn}\left(r=-0.793^{* *}, p<0.01\right)$ concentration in turmeric and $\mathrm{Mn}$ also significantly $\left(r=-0.779^{* *}, p<0.01\right)$ correlated with $\mathrm{Cr}$ concentration of turmeric. But the concentration of cupper significantly and negatively correlated with $\mathrm{Mn}$ concentration $\left(r=-0.871^{\prime \prime}, p<0.01\right)$ again $\mathrm{Cu}$ also significantly correlated with $\mathrm{Cr}\left(r=0.867^{\prime \prime}, p<0.01\right)$ concentration of turmeric.

The results from overall discussion showed that there is no risk for the daily use of the above mentioned spices for $\mathrm{Mn}, \mathrm{Cu}, \mathrm{Zn}$ if taken in limited amount. Excessive use of these could therefore pose a health hazard to consumers. But for $\mathrm{Cr}$ and Fe exceeds the permissible limit recommended by WHO, $2005^{12}$. So, it is a very concerning matter for daily use of this spicy. Among the five spots, spicy of khatungonj and chackbazar contained high concentration of heavy metals. It should require under continuous monitoring of local market of these areas to protect food chain contamination and environment pollution of Chittagong metropolitan city.

\section{ACKNOWLEDGEMENT}

The author acknowledges Phytochemistry Research Division as well was fruit and Vegetable Research Division of BCSIR. Author also acknowledges the Director of BCSIR laboratory of Chittagong, Bangladesh for his cordial co-operation to continue this research work.

\section{REFERENCES}

1. Hirasa, K. and Takemasu, M. Spice Science and Technology. Marcel Decker Inc. New York, (1998).

2. Manay, S. \& Shadaksharaswami, M. Foods- facts and Principles. New Age International Publication, New Delhi, 321-330, (1997).

3. Hinneburg I., Damien Dorman H.J., Hiltunen R. Food Chem. 97; 122, (2006). 
4. Srinivasan K. Food Res. Int. 38; 77, (2005).

5. Gupta K. K, Bhattacharjee S, Kar S., Chakrabarty S., Thakar P., Bhattacharyya G. and Srivastava S. C. Soil and plant anal. 34, 681-693, (2003).

6. Ansari T.M, Ikram N., Najam-ul-Haq M., Fayyaz O., Ghafoor I. and Khalid N. J. Biol. Sci. 4; 95-99, (2004).

7. Divrikli U, Horzum N, Soylak M, Elci L. Int. J. Food Sci. Technol., 41; 712-716, (2006).

8. Millour S, Noel L, Kadar A, Chekri R, Vastel C, Sirot V, Leblanc CJ, Guerin T. Food Chem., 126; 1787-1799, (2011).
9. Sherman, W. P. and Billing, J. Quarterly Review of Biology, 73; 1 - 47, (1998).

10. HUQ, S. I. \& ALAM, M. A handbook on analyses of soil, plant and water. BACERDU, University of Dhaka, Bangladesh, 246. (2005).

11. King J.C, Keen C.L. In: Shils M.E, Olsen J.A, Shike M, editors. Zinc Modern Nutrition in Health and Disease, 8th ed. Philadelphia, PA: Lea and Febiger, (1994).

12. World Health Organization. "Quality Control Methods for Medicinal Plant Materials", Genava, (2005). 